\title{
A PEDAGÓGUSHALLGATÓK FELKÉSZÍTÉSE A TUDÁSBAN ÉS SZOCIALIZÁLTSÁGBAN HETEROGÉN TANULÓCSOPORTOK NEVELÉSÉRE, OKTATÁSÁRA
}

\author{
K. NAGY EMESE \\ Eszterházy Károly Egyetem \\ Neveléstudományi Intézet
}

\begin{abstract}
A Komplex Instrukciós Program ${ }^{1}$ (K. Nagy, 2007, 2015) mint pedagógiai beavatkozás megpróbálja megváltoztatni az osztály szociális szerkezetét a tanulók csoportmunkája során. Ezek a változások, amelyek magukban foglalják a tanárok és tanulók új szerepének megalkotását, a tanulók együttműködésének növekedését és a különböző státuszú tanulók harmonikus részvételét, a feladat szerkezetétől, fajtájától jelentősen függnek. A csoportfeladat hatással van a résztvevők együttműködésére és a feladat végrehajtásának az eredményességére, vagyis a tanulóknak a kiscsoportokban végzett tevékenységére.

Írásunk célja annak bemutatása, hogy a pedagógusképzésben részt vevő hallgatók mennyire értik a pedagógusnak a tanulói státuszkezelésre irányuló tevékenységét, valamint az ehhez kapcsolódó, nyitott végű feladatok és a differenciált egyéni feladatok szerkesztésének fontosságát (Cohen, 1994, K. Nagy, 2007, 2015).
\end{abstract}

\section{Bevezető gondolatok}

Írásunk témája egy kutatássorozatba illeszkedik. Első lépésként a hallgatók megismerték a státuszprobléma kezelésére irányuló, a tanórán megnyilvánuló tanári magatartás jellemzőit. Ezt követően ismereteket szereztek arról, hogy a tanítási óra elemzése során hogyan tudnak különbséget tenni a tanulóközpontú, a tanulásközpontú, az értékelés-központú és a közösségközpontú ismeretelsajátítási módok között. Harmadik lépésként - és ez jelen írásunk fókusza - a hallgatók megismerték a heterogén tanulói csoport együttműködését elősegítő nyitott végü feladatok szerkesztésének és az egyénre szabott differenciált feladatok kijelölésének fontosságát a feladatillusztrációk elkészítésén keresztül.

1 A Komplex Instrukciós Program/KIP olyan tanítási eljárás, amely lehetővé teszi a tanárok számára a magas szintű csoportmunka szervezését olyan osztályokban, ahol a tanulók közötti tudásbeli és kifejezőkészségbeli különbség tág határok között mozog, és az osztályban végzett munka eredményeként a hátrányos helyzetű tanulók leszakadását lassítja, illetve megakadályozza, a tehetségesebbekét pedig előmozdítja. A KIP a tanulókat életszerű és élményszerủ személyes tapasztalatokhoz juttatja az iskolai munka során (K. Nagy, 2015). 
A feladat sikeres végrehajtása érdekében a hallgatók előzményként megismerték a tudásban heterogén tanulói összetétel kezelésére alkalmas Komplex Instrukciós Programot (továbbiakban KIP), majd megtekintettek és adott szempontok alapján elemeztek négy, a módszer elveinek megfelelően felépített tanítási óráról készült videófelvételt. Ezt követően a KIP elveinek megfelelő 45 perces tanóra-szimuláción vettek részt, majd három, a KIP szerint szerkesztett feladatillusztrációt elemeztek. Csak ezután következett az önálló, oktatói segítség nélküli, a KIP elveinek megfelelö, a tudásban heterogén tanulói csoportot figyelembe vevő, azt kezelő feladatillusztráció összeállítása, amelyre javított, elemzett és írásos formában visszajelzést kaptak a hallgatók (1. táblázat).

\begin{tabular}{|c|c|c|c|c|c|}
\hline Intézmény & $\begin{array}{l}\text { Vizsgálat } \\
\text { éve }\end{array}$ & Szak & $\begin{array}{l}\text { Nappali } \\
\text { hallgatók } \\
\text { száma/fó }\end{array}$ & $\begin{array}{l}\text { Levelező } \\
\text { hallgatók } \\
\text { száma/fó }\end{array}$ & Összesen/fö \\
\hline \multirow[t]{2}{*}{ EKE } & 2018 & \multirow{2}{*}{$\begin{array}{l}\text { Tantárgy szakos } \\
\text { tanárképzésben részt vevő } \\
\text { hallgatók }\end{array}$} & 26 & 19 & 45 \\
\hline & 2019 & & 25 & 25 & 50 \\
\hline \multirow[t]{2}{*}{ ELTE } & 2018 & \multirow[t]{2}{*}{ Fejlesztőpedagógus hallgatók } & 0 & 37 & 37 \\
\hline & 2019 & & 0 & 36 & 36 \\
\hline Összesen & & & 51 & 117 & 168 \\
\hline
\end{tabular}

1. táblázat. A vizsgálatban részt vevök száma

A feladatillusztrációkat a hallgatók a szemináriumi foglalkozások zárásaként, elméleti ismereteik és óraszimulációs tapasztalataik birtokában, valamint a videófilmeken látottak alapján készítették el. A bírálatban a legfontosabb szempont a KIP elveinek való megfelelés, vagyis a csoportfeladatok nyitottvégüsége, a többféle képesség felhasználásának az igénye, vagyis a feladat komplexitása és a csoport, illetve az egyéni feladatok kapcsolatának adott szempont alapján való érvényesítése volt.

Vizsgáltuk, hogy képes-e a hallgató olyan óraterv összeállítására, amely a több helyes megoldást magukban foglaló nyitott végű feladatokon keresztül a diákoknak lehetőséget nyújt a tudásban heterogén, 4-5 fös tanulói csoporton belül alternatív megoldások keresésére, érveik bizonyítására és a vitára. Az összetett, multidimenzionális csoportfeladatok követelménye, hogy megoldásuk sokféle intellektuális képességet igényel, lehetőséget adva a diákoknak tehetségük, tudásuk és problémamegoldó képességük használatára, fejlesztésére, szem előtt tartva, hogy minél összetettebb egy feladat, annál több diáknak van lehetősége megmutatni és fejleszteni intellektuális képességét. Kiemeltük annak fontosságát, hogy az összetett képességek fejlesztése nagy jelentőséggel bír, mivel nélkülözhetetlen eszköz a státuszprobléma sikeres kezelésében, alkalmat adva a tanulóknak, de a pedagógusképzésben 
részt vevő hallgatónak is arra, hogy kialakítsák, formálják a nézetüket azzal kapcsolatban, hogy mit jelent a diák szempontjából kompetensnek és „tehetségesnek” lenni.

A hallgató a feladatillusztráció készítésekor figyelembe vette, hogy a nyitott végü, több megoldást lehetővé tévő, összetett képességeket igénylő gyakorlatokon keresztül nyílik alkalma arra, hogy a tanulók egymástól való függését erősítése. Ez a kölcsönös függőség figyelmet kíván a tanulóktól együttműködésükben és közös döntéseikben. Egy olyan csoportban, ahol a csoporttagok egymással függőségi viszonyban állnak, ott az együttmüködés és az interakció iránt fokozottabb igény jelentkezik, amelynek jelentősége a komplex és ismeretlen feladatok miatt még kifejezettebb. A csoportmunka célja ennek a közös egymásra utaltságnak, munkának a megfelelő szinten tartása, erősítése. A csoportmunkára támaszkodó egyéni feladatok az önálló munkára való képesség bemutatásának a legfontosabb szóbeli és írásbeli dokumentumai, segítségükkel a tanuló lehetőséget kap a fejlődésre, a gyakorlásra és íráskészsége fejlesztésére, és egyben lehetőséget nyújt a tanár számára a diák egyéni haladásának a méréséhez.

Felhívtuk a hallgatók figyelmét arra, hogy a csoportmunka különösen akkor eredményes, amikor a tanár legfontosabb célja a fogalmak elsajátíttatása, a problémamegoldó gondolkodás fejlesztése és a feladat megértetése. Ehhez a diákoknak a feladatokon keresztül alkalmat kell nyújtani a vitára és gondolataik érthető megfogalmazására. Ezért a körültekintően szervezett csoportmunka vagy egy központi gondolat köré szerveződik, vagy egy lényeges kérdésre keres választ. A hallgatókat felkészítettük arra is, hogy a jó feladat megtervezéséhez a pedagógusnak hosszú időre, alapos felkészülésre, elméleti ismeretre van szüksége, vagyis a jól megtervezett feladat a tanár szakmai fejlődését épp úgy szolgálja, mint a diákokét.

Az egyetemi kurzusok befejezéseként a hallgatók elkészítették a feladatillusztrációikat, amelyek elemzésekor az alábbi jellemző hibákkal találkoztunk:

- a csoportfeladatok nem feleltek meg a nyitottvégüség követelményének, nem adtak alkalmat a tanulók közötti vitára, így a kommunikáció erősítésére;

- olykor az ötletből kifogyva a pedagógusok minden csoportnak azonos feladatot adtak az osztályon belül, ezzel teremtve versenyhelyzetet, amely demotiválóan hathat egy-egy csoport munkájára;

- a csoportfeladatok nem voltak eléggé és egyformán kihívóak, motiválóak;

- a pedagógusok túlméretezték időben a csoportfeladatokat, így ezt követően a tanulóknak a tanórán nem maradt idejük a személyre szabott, egyéni feladatok megoldására;

- a differenciált egyéni feladatok nem használták fel a csoportmunka eredményét, így a tanulók nem tartották fontosnak a közös munkát, mivel egyéni sikerük nem attól függött.

A továbbiakban ezeket a tipikus hibákat elemezzük az egyes szakok és tagozatok hallgatói teljesítményének összehasonlításával. 


\section{A csoportfeladatok nem feleltek meg a nyitottvégüség követelményének}

Az adatok összegzéséből kiderül, hogy sem a nappali, sem a levelező tagozatos, sem a fejlesztőpedagógus szakos hallgatók csoportja elsőre nem tudta 100\%-ban teljesíteni azt a követelményt, hogy az összeállított feladatok nyitott végüek, valamint minden esetben a heterogén tanulói kiscsoport minden tagja számára motiválóak legyenek. Alacsony volt azoknak a hallgatóknak az aránya, akik ennek a követelménynek megfelelő óratervet tudnak készíteni. Ennek a hiányosságnak a következménye a csoporton belüli vita elmaradása, a kisebb intenzitású kommunikáció lesz, ami végső soron az ismeretelsajátítást lassítja, hiszen minél kevesebbet beszélgetnek a tanulók az ismeretekről, a tananyagról, annál kevesebbet tanulnak. Születtek olyan feladatillusztrációk is, amelyekben a nyitottvégűség a csoportfeladatok egy részében érvényesült, majd - talán az ötletekből való kifogyás miatt - zárt végű feladatokkal zárultak. Ezek a részben megfelelő kategóriába sorolt tervek.

Az adatok elemzésekor az is kiderült, hogy a fejlesztőpedagógusok értették meg legjobban és a levelező tagozatos hallgatók a legkevésbé a nyitottvégűség lényegét (2. táblázat, 1. ábra). Az elemzés során végzett Khí-négyzet próba alapján ezek az eltérések nem szignifikánsak (3. táblázat). ${ }^{2}$

\begin{tabular}{|c|c|c|c|c|}
\hline Szak, tagozat & $\begin{array}{c}\text { Hallgatók } \\
\text { száma/fó }\end{array}$ & $\begin{array}{l}\text { Nem megfelelően } \\
\text { nyitott végü } \\
\text { feladat } \%\end{array}$ & $\begin{array}{c}\text { Részben } \\
\text { megfelelő feladat } \\
\%\end{array}$ & $\begin{array}{c}\text { Megfelelő feladat } \\
\%\end{array}$ \\
\hline Nappali tagozat & 51 & $72,5 \%$ & $13,7 \%$ & $13,7 \%$ \\
\hline Levelező tagozat & 44 & $75,00 \%$ & $15,9 \%$ & $9,1 \%$ \\
\hline $\begin{array}{c}\text { Fejlesztő } \\
\text { pedagógus }\end{array}$ & 73 & $57,5 \%$ & $21,9 \%$ & $20,5 \%$ \\
\hline Összesen & 168 & - & - & - \\
\hline
\end{tabular}

2. táblázat. A feladatok nyitottvégüségének megfelelése a hallgatói csoportok között

2 Sig > 0,05. Ebben az is közrejátszhat, hogy - ugyan a vizsgálat minden, a programot használó hallgatóra kiterjedt - a minta elemszáma alacsonynak tekinthető. 


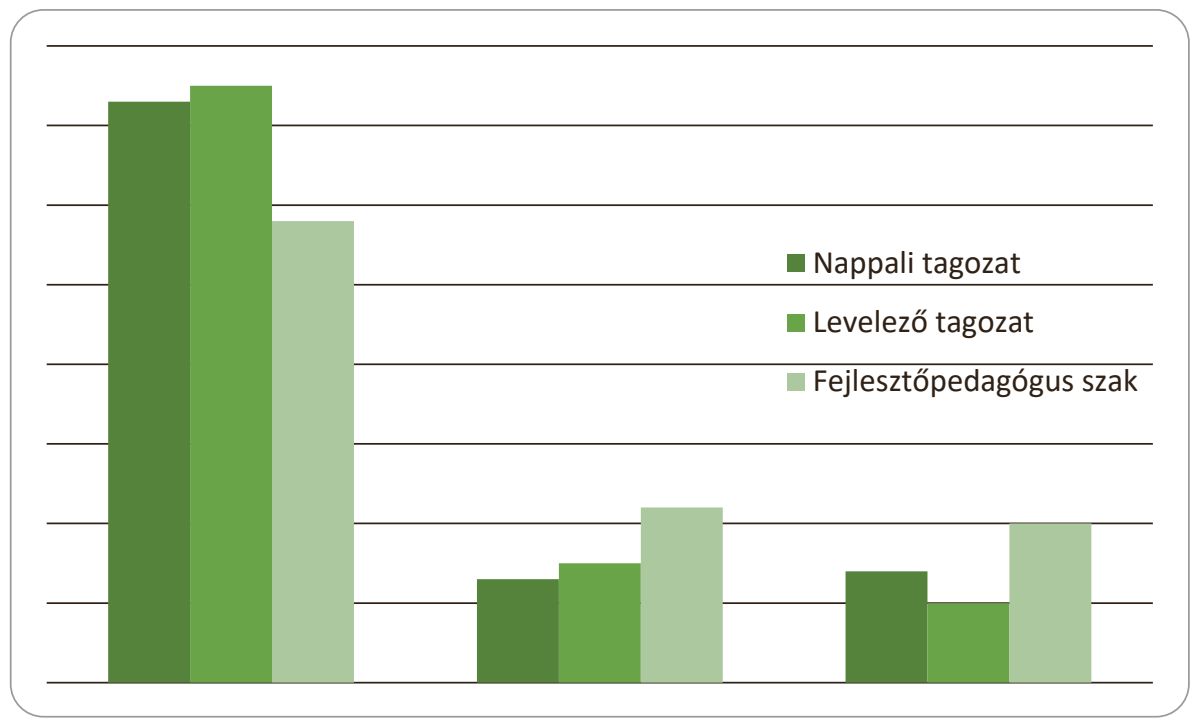

1. ábra. A feladatok nyitottvégüségének megfelelése a hallgatói csoportok között

\begin{tabular}{|l|l|l|l|}
\hline & Érték & df & Asymp. Sig. \\
\hline & & Szabadságfok & $\begin{array}{l}\text { (2-sided) } \\
\text { Szignifikancia }\end{array}$ \\
\hline $\begin{array}{l}\text { Khí-négyzet/ } \\
\text { Pearson-féle eloszlás }\end{array}$ & $5,365 \mathrm{a}$ & 4 & 0,242 \\
\hline $\begin{array}{l}\text { Valószínúségi } \\
\text { hányados }\end{array}$ & 5,478 & 4 & 0,242 \\
\hline $\begin{array}{l}\text { Linear-by-Linear } \\
\text { Association }\end{array}$ & 2,984 & 1 & 0,084 \\
\hline Érvényes esetek száma & 168 & & \\
\hline
\end{tabular}

3. táblázat. A csoportfeladatok nem feleltek meg a nyitottvégüség követelményének

\section{A csoportok azonos feladatot kaptak}

Ha ma megkérdezzük a pedagógusokat, hogy használnak-e csoportmunkát, kooperatív technikát tanítási óráikon, akkor mindenki igennel válaszol. Az alkalmazás gyakoriságában, illetve az alkalmazás tudatosságában azonban jelentős eltérések vannak.

A Komplex Instrukciós Programot alkalmazó pedagógusoknak tisztában kell lenniük azzal, hogy a tanulók státuszhelyzetének a javításához, a gyerekek között kialakult rangsor rendezéséhez, a tanulók motiválásához jelentősen hozzájárul a csoportfeladatok nyitottsága 
mellett az is, hogy az egyes tanulói csoportok eltérő feladatot kapnak. Ennek a jelentősége abban rejlik, hogy azonos feladat megoldása esetén az a csoport, amelynek a feladathoz legjobban értő tanuló a tagja, nagy valószínűséggel magasabb szinten oldja meg a feladatot, mint a többi csoport. Összehasonlítva a csoportmunkákat hamar kialakul az a vélemény a tanulók között, hogy abban a csoportban érdemes dolgozni, ahol a legjobb képességű(ek) van(nak), hisz ők oldják meg legmagasabb szinten a feladatot. Ez versenyhelyzetet teremt, ami sok tanulóra, különösen a tanulásban lemaradtakra negatív hatással van. A KIP-órákon, amelyek a tanítási órák 10-20\%-át teszik ki, a tanulói csoportok közötti versenyeztetés (és 1-5-ig terjedő érdemjegy adása is) hátrány.

A hallgató lustaságából is eredhet az azonos feladatok kijelölése, de arra is gondolhatunk, hogy a hallgató nem értette meg a módszer státuszkezelő és motiváló lényegét (4. táblázat, 2. ábra).

Az ábrából leolvasható, hogy a fejlesztőpedagógusok tudták leginkább alkalmazni a feladatillusztráció készítésében azt az ismeretet, miszerint ha minden csoport eltérő feladatot kap, akkor a csoportok közötti versenyhelyzet kiiktatásra kerül, ami az alulteljesítőkre, a stresszhelyzetet kevésbé tűrőkre motiválóan hat. Azt is láthatjuk, hogy a levelező tagozatosok ebben az esetben is rosszabbul teljesítettek, mint a nappali tagozatosok és a fejlesztő pedagógia szakosak. Ezek az összefüggések szintén nem tekinthetők szignifikánsnak. ${ }^{3}$

\begin{tabular}{|c|c|c|c|c|}
\hline Szak, tagozat & $\begin{array}{c}\text { Hallgatók } \\
\text { száma/fó }\end{array}$ & $\begin{array}{c}\text { Azonos csoport- } \\
\text { feladatok \% }\end{array}$ & $\begin{array}{c}\text { Részben azonos } \\
\text { csoportfeladatok } \\
\%\end{array}$ & $\begin{array}{c}\text { Eltéró csoport- } \\
\text { feladatok \% }\end{array}$ \\
\hline & & & & $15,7 \%$ \\
\hline Nappali tagozat & 51 & $64,7 \%$ & & $19,6 \%$ \\
\hline & & & $18,2 \%$ & $11,4 \%$ \\
\hline Levelező tagozat & 44 & $70,5 \%$ & & $27,4 \%$ \\
\hline Fejlesztöpedagógus & 73 & $47,9 \%$ & $24,7 \%$ & \\
\hline & & & & - \\
\hline Összesen & $\mathbf{1 6 8}$ & - & & \\
\hline
\end{tabular}

4. táblázat. Azonos csoportfeladatok kijelölésének az aránya a szakos és a tagozatos hallgatók körében

3 Khí-négyzet próba, Sig. > 0,05. 


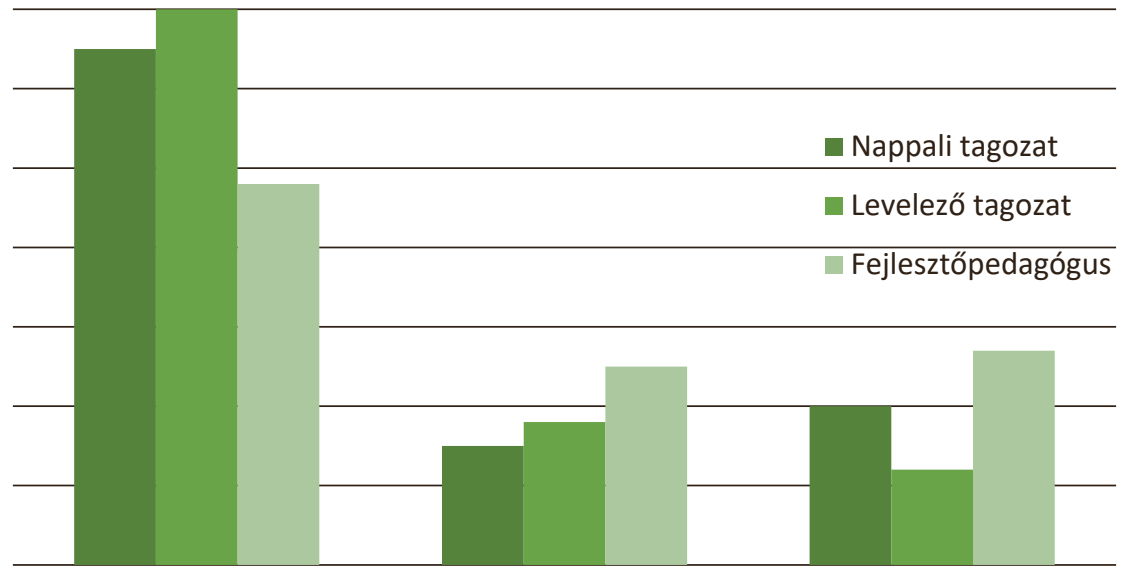

2. ábra. Azonos csoportfeladatok kijelölésének az aránya a szakos és a tagozatos hallgatók körében

\section{A csoportfeladatok nem voltak eléggé és egyformán kihívóak, motiválóak}

Még a gyakorló pedagógusokat is próbára teszi az a követelmény, hogy a tanulók részére olyan eltérő feladatokat állítsanak össze, amelyek egy osztály kis tanulócsoportjai számára adott témában egyformán érdekesek, figyelemfelkeltőek, motiválóak (5. táblázat. 3. ábra).

\begin{tabular}{|c|c|c|c|}
\hline Szak, tagozat & $\begin{array}{c}\text { Hallgatók } \\
\text { száma/fó }\end{array}$ & $\begin{array}{c}\text { Kevésbé motiváló } \\
\text { feladatok \% }\end{array}$ & $\begin{array}{c}\text { Megfelelöen moti- } \\
\text { váló feladatok \% }\end{array}$ \\
\hline & & & \\
\hline Nappali tagozat & 51 & $45,1 \%$ & $54,9 \%$ \\
\hline & & & \\
\hline Levelező tagozat & 44 & $27,3 \%$ & $72,7 \%$ \\
\hline & & & \\
\hline Fejlesztőpedagógus & 73 & $27,4 \%$ & $72,6 \%$ \\
\hline & & & \\
\hline Összesen & $\mathbf{1 6 8}$ & - & - \\
\hline
\end{tabular}

5. táblázat. Motiváló csoportfeladatok aránya a szakos és a tagozatos hallgatók körében 


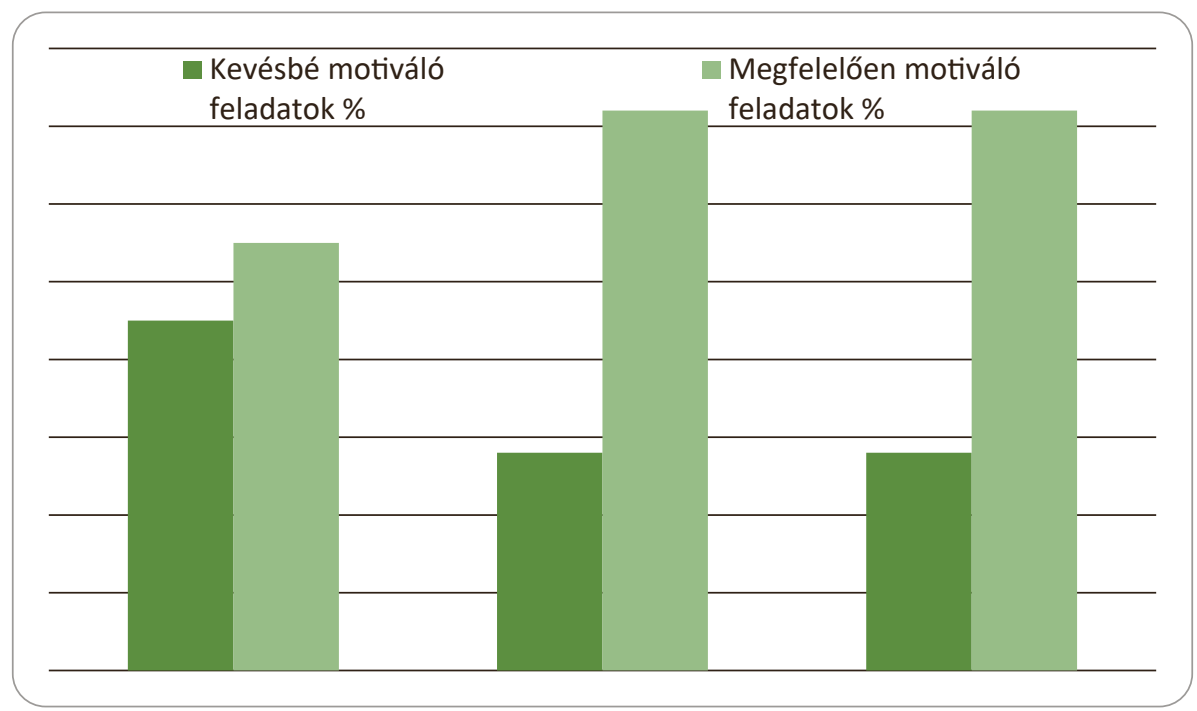

3. ábra. Motiváló csoportfeladatok aránya a szakos és a tagozatos hallgatók körében

Izgalmas, mégis előre feltételezett eredményt kaptunk az összeállított feladatok motiváló hatását illetően. Az adatok elemzéséből kiderül, hogy a nappali tagozatos hallgatóknak kisebb arányban sikerült a megfelelően motiváló feladatok kialakítása. Véleményünk szerint ez annak tulajdonítható, hogy nincs jártasságuk és tapasztalatuk a feladatok összeállításában, a tananyaggal, ismeretekkel való bánásban. Az is kiderült, hogy a levelező tagozatos és a fejlesztő pedagógia szakos hallgatók, vagyis a gyakorló pedagógusok azonos arányban tudtak egyformán kihívó, érdekes feladatokat összeállitani. Viszont az is látható, hogy közülük minden harmadik, negyedik személynek, feltételezhetően nemcsak mint hallgatónak, hanem mint gyakorló pedagógusnak is, küzdenie kell azért, hogy képes legyen motiváló feladatokat összeállítani a gyerekek számára. Márpedig ez a tanulók motiválásának az egyik követelménye. A képzett csoportok körében megfigyelt arányok közötti különbségek nem szignifikánsak. ${ }^{4}$

\section{A hallgatók túlméretezték időben a feladatokat}

Annak megállapítása, hogy egy csoportfeladat az adott időintervallumba (a tanítása óra 20-25 perce) belefér-e, nagy gyakorlatot igényel. Ezt a legnagyobb biztonsággal a program alkalmazásában jártas gyakorló pedagógusok tudják megítélni.

4 Khí-négyzet próba, Sig. > 0,05. 
Méréseink szerint a nappali tagozatos hallgatók, gyakorlati tapasztalatok hiánya miatt, túlméretezték a feladatokat. A túlméretezett feladatok eredménye, hogy nem teszik lehetővé (idő hiányában) a 45 perces tanórán a csoportfeladatot követően a tanulók személyre szabott egyéni fejlesztését. Márpedig a Komplex Instrukciós Program szerinti óra fele a kis tanulói csoportok által megoldandó feladatok számára van fenntartva, és az óra többi része a csoportfeladat eredményét felhasználó differenciált egyéni feladatok megoldására áll rendelkezésre (6. táblázat, 4. ábra).

\begin{tabular}{|c|c|c|c|}
\hline Szak, tagozat & Hallgatók száma/fó & $\begin{array}{c}\text { Túlméterezett } \\
\text { feladatok \% }\end{array}$ & $\begin{array}{c}\text { Megfelelö hosszúságú } \\
\text { feladatok \% }\end{array}$ \\
\hline & & & \\
\hline Nappali tagozat & 51 & $47,1 \%$ & $52,9 \%$ \\
\hline & & & $77,3 \%$ \\
\hline Levelező tagozat & 44 & $22,7 \%$ & $72,6 \%$ \\
\hline & & & \\
\hline Fejlesztőpedagógus & 73 & $27,4 \%$ & - \\
\hline & & & - \\
\hline Összesen & $\mathbf{1 6 8}$ & & \\
\hline
\end{tabular}

6. táblázat. A csoportfeladatok hossza az egyes hallgatói csoportokban

A gyakorlottság, a tapasztalat a siker egyik záloga. Az elméleti ismeretek elsajátítása és annak a gyakorlatban történő alkalmazása a levelező tagozatos hallgatók esetében a pedagóguspályán eltöltött időnek tulajdoníthatóan könnyebb. Tapasztalatukból eredően ez a csoport könnyebben fel tudja mérni az egyes feladatok megoldásához szükséges időt. Lényegtelen az eltérés, mindössze $2 \%$ a levelező tagozatos és a fejlesztőpedagógus szakos hallgatók között, ez utóbbi csoport javára.

A csoportfeladatok hosszának, méretezésének szempontjából tapasztalt összefüggés szignifikánsnak mutatkozott, ami arra enged következtetni, hogy ezek az eltérések valóban a különböző hallgatói csoportoknak (nappali vagy levelező tagozat, illetve fejlesztőpedagógusok) tulajdoníthatóak. ${ }^{5}$

5 Khí-négyzet próba, Sig. $<0,05$. 


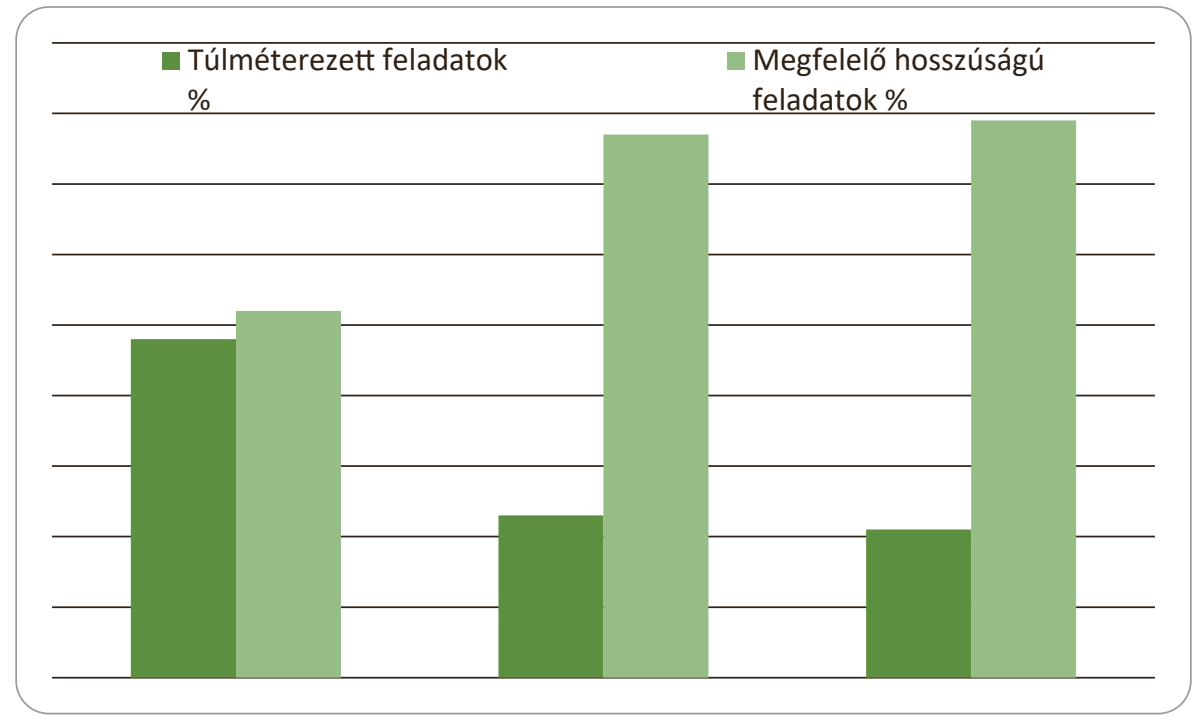

4. ábra. A csoportfeladatok hossza az egyes hallgatói csoportokban

\section{A differenciált egyéni feladatok nem használták fel a csoportmunka eredményét}

A tanulók tudásának a fejlesztése nagyban függ a személyre szabott feladatoktól, az egyéni, differenciált fejlesztéstől. A Komplex Instrukciós Programban a differenciált egyéni feladatok szerkesztése az egyik legnagyobb figyelmet igénylő feladat. Nemcsak azért, mert névre szól, figyelembe veszi a tanuló meglévő tudását, ismereteit, vagyis épít Vigotszkij legközelebbi fejlődési zóna elméletére (Vigotszkij, 1978), hanem azért is, mert visszahat a tanulók csoporton belüli együttmüködésére is. Ennek az eszköze az, hogy az egyéni feladatoknak fel kell használniuk a csoportmunka eredményét, vagyis nem lehet megoldani azokat anélkül, hogy a csoportfeladat ne készüljön el, ne vegyen részt benne a tanuló, és ne támaszkodjon az ott szerzett ismeretekre. Ha a tanuló számára nem tesszük lehetővé, hogy az egyéni feladatában felhasználja a csoportmunka eredményét, akkor a csoportmunkában való aktív részvételről szoktatjuk le. Ennek a kívánalomnak az elmulasztásánál hamar megtanulja a diák, hogy az egyéni feladata akkor is sikerül, ha nem vesz részt a csoportmunkában, ami a csoport együttműködése szempontjából hátráltató tényező. Ellenkező esetben viszont azt tudatosítjuk a tanulóban, hogy a csoport sikere az ő egyéni előrehaladásának is a záloga. Vizsgálatunk célja annak megállapítása volt, hogy meglévő ismereteik birtokában képesek-e a hallgatók olyan feladatokat összeállítani, amelyek a csoportmunka során szerzett ismeretekre támaszkodnak, annak eredményét felhasználva fejlesztik a gyerekek tudását, motiválják munkára őket. 
Az összes vizsgált hallgató tekintetében nagy különbségeket látunk a névre szóló, egyéni képességekhez mért feladatok megfelelésében (7. táblázat, 5. ábra).

\begin{tabular}{|c|c|c|c|c|}
\hline Szak, tagozat & $\begin{array}{c}\text { Hallgatók } \\
\text { száma/fó }\end{array}$ & $\begin{array}{c}\text { Nem használták } \\
\text { fel \% }\end{array}$ & $\begin{array}{c}\text { Részben használ- } \\
\text { ták fel \% }\end{array}$ & Felhasználták \% \\
\hline & & & & \\
\hline Nappali tagozat & 51 & $9,8 \%$ & $13,7 \%$ & $76,5 \%$ \\
\hline & & & & \\
\hline Levelező tagozat & 44 & $15,9 \%$ & $11,4 \%$ & $72,7 \%$ \\
\hline & & & & \\
\hline Fejlesztőpedagógus & 73 & $1,4 \%$ & $2,7 \%$ & $95,9 \%$ \\
\hline & & & & \\
\hline Összesen & $\mathbf{1 6 8}$ & - & - & - \\
\hline
\end{tabular}

7. táblázat. A differenciált egyéni feladatok megfelelése az egyes hallgatói csoportokban

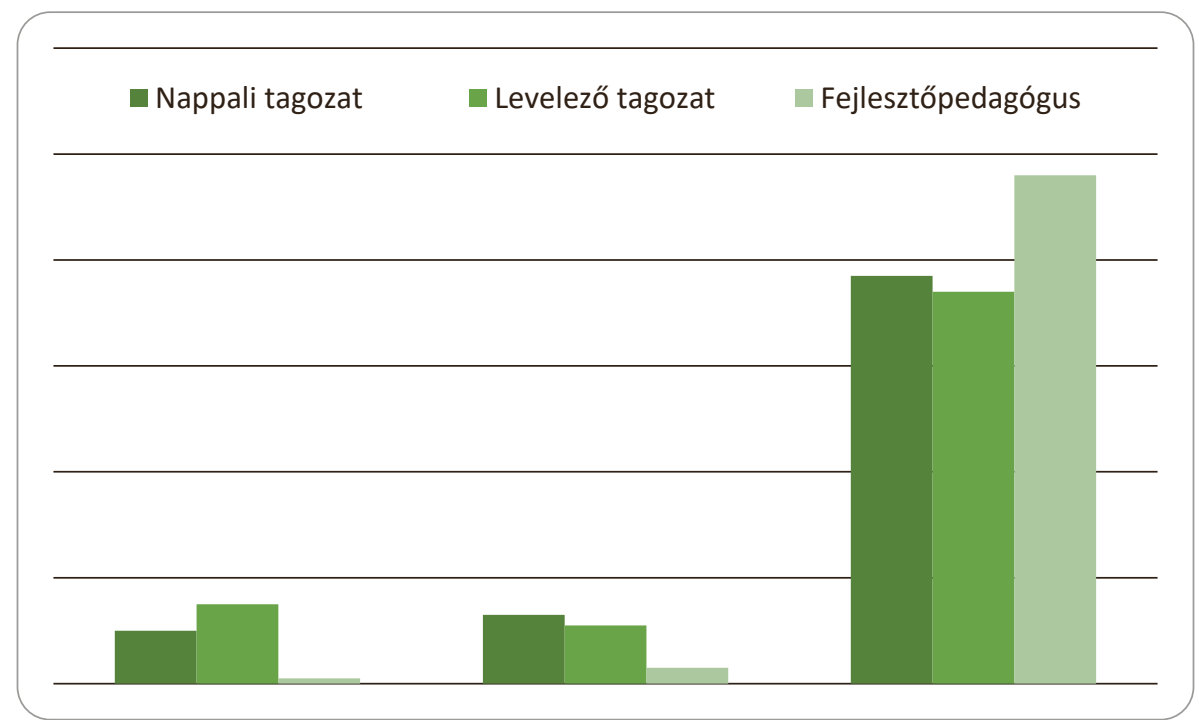

5. ábra. A differenciált egyéni feladatok megfelelése az egyes hallgatói csoportokban

A fejlesztőpedagógusok kiemelkedően magasabb arányban, 96\%-ban készítették el a kritériumoknak megfelelően a differenciált egyéni feladatokat, és ez az eltérés egyértelmüen szignifikánsnak tekinthető. ${ }^{6}$ Közülük csak egy hallgató nem értette meg a csoportfeladatra

6 Khí-négyzet próba, Sig. $<0,05$. 
történő ráépülés lényegét, fontosságát. Mivel az ő feladatuk, munkájuk elsődleges célja a tanuló egyénre szabott fejlesztése, az sem meglepő, hogy közülük mindenki az integrációs mátrixnak megfelelően (Bloom-féle taxonómia, Gardner-féle többszörös intelligencia), annak értő alkalmazásával készítette el a tanulók egyéni feladatát.

\section{Javításra visszaküldött óratervek}

Összességében kevés volt azoknak a hallgatóknak a száma, akiknek az óraterve a Komplex Instrukciós Program elveinek teljes mértékben megfelelt. Csak kevesen voltak képesek (természetesen) az összes, a programnak megfelelő kritérium egy időben történő figyelembevételére, illetve az eddigi tapasztalatuk, tudásuk átgondolására, formálására. A fenti vizsgálati szempontoknál kapott eredményekhez hasonlóan, azok eredőjeként a fejlesztőpedagógusok teljesítménye a legjobb e tekintetben. Ök értették meg legjobban a módszer kritériumait, annak a tanításban történő alkalmazását. Az ő esetükben kértük legkisebb arányban a feladatillusztráció újrafogalmazását - és ez a csoportok közötti eltérés is szignifikánsnak tekinthető. ${ }^{7}$ Viszont az értékekből az is kiderül, hogy mindegyik hallgatói csoport tekintetében jelentős a javításra visszaadott munka (8. táblázat, 6. ábra).

A javításra visszaküldött óratervek magas aránya arra enged következtetni, hogy nehéz megváltoztatni a pedagógusok, a leendő pedagógusok „tanításról” vallott nézeteit. Mind a nappali, mind a levelező tagozatos hallgatóknak a diákéveikből hozott tapasztalataikhoz köthető elképzelései vannak a tanításról. Legtöbbjük a pedagógusi munkát az új ismeret szóbeli közlésével azonosítja, a minél érthetőbb és logikusabb magyarázatok láncolatával. Elképzeléseik nem igazodnak a tanítással szemben támasztott új követelményekhez. A váltás nehéz. Problémát jelent számukra olyan összetett, multidimenzionális csoportfeladatokat összeállítani, hogy megoldásuk sokféle intellektuális képességet igényeljen, lehetőséget adva a diákoknak tehetségük, tudásuk és problémamegoldó képességük használatára, fejlesztésére, szem előtt tartva, hogy minél összetettebb egy feladat, annál több diáknak van lehetősége megmutatni és fejleszteni intellektuális képességeit. Az összetett képességek fejlesztése nagy jelentőséggel bír, mivel nélkülözhetetlen eszköz a tanulók tekintetében fennálló státuszprobléma sikeres kezelésében.

7 Khí-négyzet próba, Sig. < 0,05. 


\begin{tabular}{|c|c|c|c|}
\hline Szak, tagozat & Hallgatók száma/fö & $\begin{array}{c}\text { Visszaküldött } \\
\text { feladatok } \%\end{array}$ & $\begin{array}{c}\text { Elfogadott feladatok } \\
\%\end{array}$ \\
\hline & & & $5 \%$ \\
\hline Nappali tagozat & 51 & $95 \%$ & $3 \%$ \\
\hline Levelező tagozat & 44 & $97 \%$ & $14 \%$ \\
\hline Fejlesztőpedagógus & 73 & $86 \%$ & \\
\hline & & & - \\
\hline Összesen & $\mathbf{1 6 8}$ & - & \\
\hline
\end{tabular}

8. táblázat. A javitásra visszaküldött óratervek az egyes hallgatói csoportokban

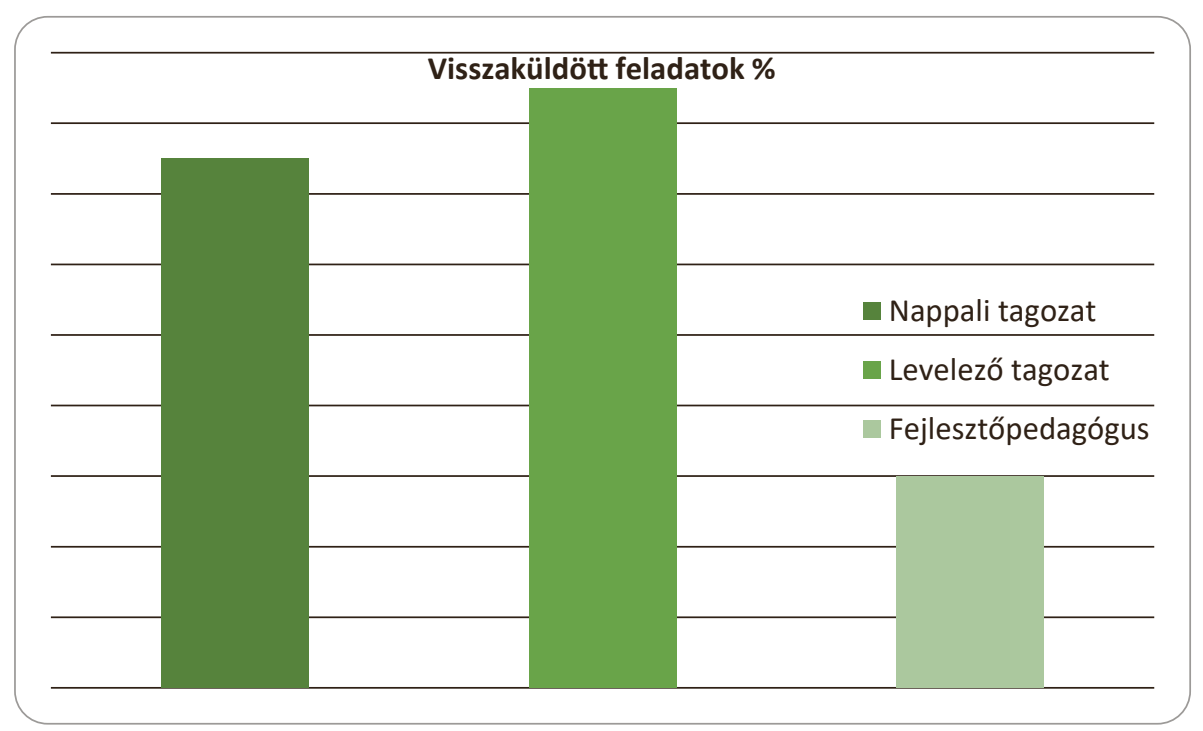

6. ábra. A javitásra visszaküldött óratervek az egyes hallgatói csoportokban

\section{Program megértését ellenőrző kérdőívek}

Vizsgálatainkban 168 tanításióra-tervet értékeltünk, majd egy, a KIP megértését ellenőrző kérdőív kitöltésére kértük a hallgatókat. Az ellenőrzés során rákérdeztünk a Komplex Instrukciós Program céljára, legfóbb ismérveire, a kiscsoportos osztálytermi szervezés eljárásaira és a státuszproblémák kezelésére. Mérni kívántuk, hogy mennyiben segítette a visszajelzés, az órai munka elemzése a hallgatót a csoportmunka pontosabb megértésében. A feleletkifejtő kérdőívek (1. számú melléklet) alapján a válaszokat az alábbiakban összegezzük. 


\section{A Komplex Instrukciós Program alkalmazásának céljai}

A pedagógusok 100\%-a jelölte meg a program legfontosabb céljául a tanulók hierarchikus sorrendjébe való beavatkozást, a státuszkezelést. További 94\% gondolta, hogy a KIP egyik fontos célja a tanár szakmai hozzáértésének fejlesztése a csoportmunka-szervezés során. A válaszok 84\%-ában történt utalás a pedagógus közvetett irányitó szerepének fejlesztésére, és további $68 \%$ a tanulók önálló döntéshozatalának és ismeretelsajátításnak tulajdonított fontos szerepet (7. ábra).

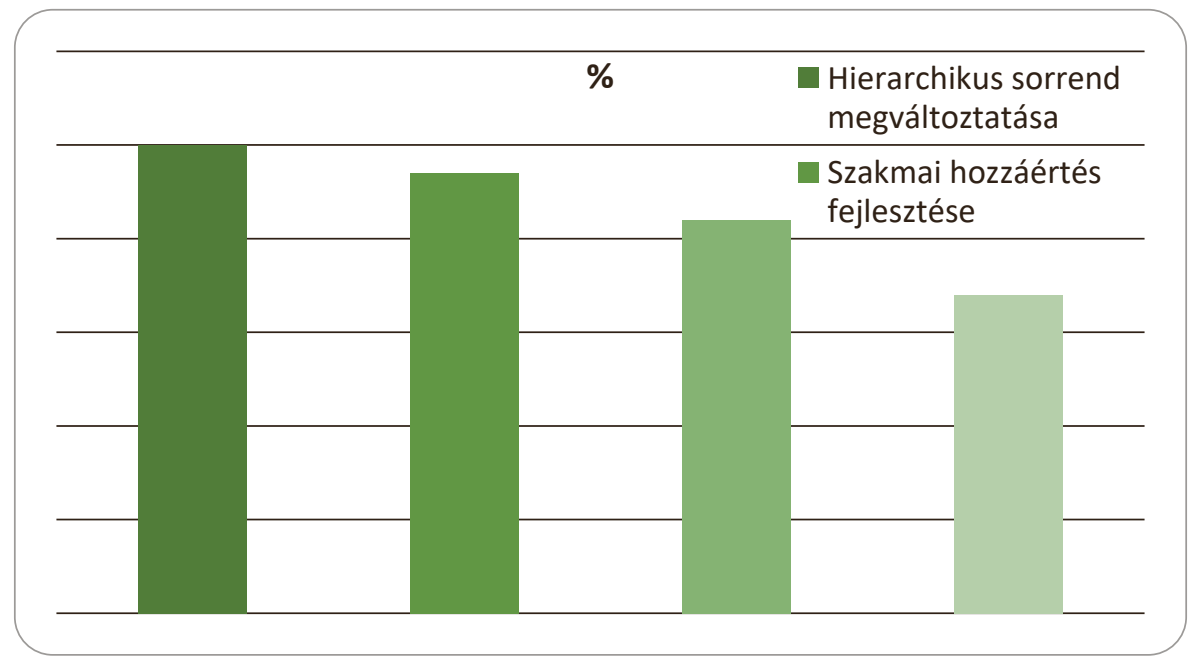

7. ábra. A Komplex Instrukciós Program alkalmazásának a céljai

Az eredményekből kitűnik, hogy minden hallgató a módszer egyik legfontosabb céljának a tanulók közötti státuszrangsor, a hierarchikus sorrend rendezését tartja. Megértették, hogy a státusz egy sorrendben elfoglalt hely, a tanulók közötti olyan elfogadott rétegződés, amelyben minden gyerek érzi, hogy jobb magasabban, mint alacsonyabban elhelyezkedni. Tudatosodott bennük, hogy azok a tanulók, akik a közösségből társadalmi okok miatt kirekesztődnek, vagy azok, akiknél tanulásukban lemaradás tapasztalható, gyakran vonakodnak részt venni a közös munkában, emiatt azonban kevesebbet tanulnak, mint azok, akik aktívabbak. Ha az osztálymunka során a tanulók nem egyenlő mértékben vesznek részt a munkában, a tanulásban történő előrehaladás egyenlőtlen lesz. Az osztályrangsor élén elhelyezkedő tanulók nagyobb befolyást gyakorolnak a csoport döntéshozatalára, gyakrabban kérik őket segítségadásra, és több alkalom jut véleményük kifejtésére, mint a rangsor alján elhelyezkedőknek, akiknek véleményét általában figyelmen kívül hagyják. Ennek a helyzetnek a kezelésére kínál megoldást a módszer. 


\section{Komplex Instrukciós Program legfőbb ismérvei}

A pedagógusok 75\%-a jelölte meg a módszer legfontosabb ismérveként, hogy az osztályon belüli rangsorbeli problémák felismerhetőkké és kezelhetőkké válnak. 72\% gondolta, hogy a csoportfoglalkozások alatt a heterogén összetételü osztályokban lehetőség nyílik a tanulóknak az együttműködési szabályokra történő felkészítésére, továbbá 63\%, hogy lehetőség adódik sokféle, eltérő képességet megmozgató tananyag alkalmazására. A megkérdezettek szintén 64\%-a gondolta, hogy a módszer egyik fontos ismérve a tanulók magasabb szintü gondolkodásának előmozdítása egy központi téma köré szervezett nyitott végű, több megoldást kínáló feladat segítségével (8. ábra).

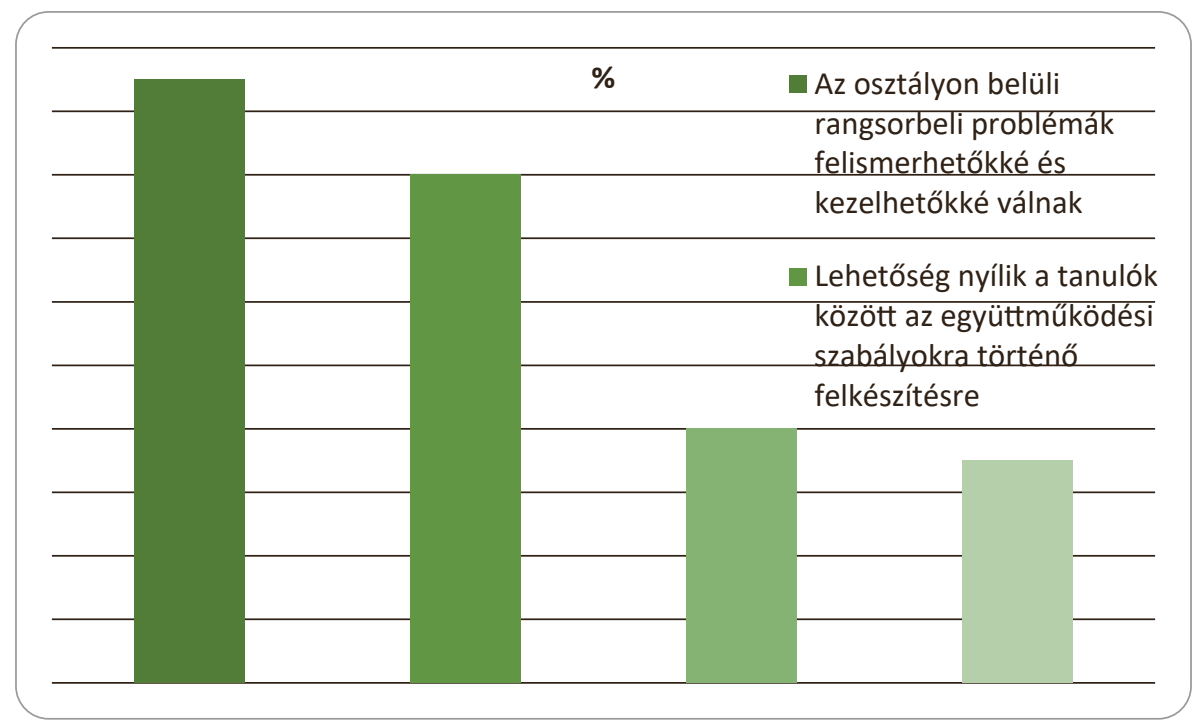

8. ábra. A Komplex Instrukciós Program legfóbb ismérvei

A hallgatók által felsorolt legfóbb ismérvek tudása, számontartása, jövőbeni munkájukban történő felhasználása lehetőséget nyújt arra, hogy úgy építsék fel a tanítási órát, hogy az alkalmazkodjon a heterogén tanulói csoport összetételéhez, figyelembe vegye minden gyereknek a képességét, és ezt az eltérő képességet a tanulók közötti együttműködés elősegítésére fordítsa. Így a magasabb szintű gondolkodásra ösztönzés, a tanulók közötti kommunikáció erősítése az ismeretelsajátítás fontos eszköze. 


\section{Kiscsoportos osztálytermi szervezés előnyei}

A válaszok többségéből kitűnik, hogy a hallgatók úgy vélik, hogy a csoportfeladatok és a tudásban heterogén összetételü csoportok együttműködése az órákon kedvező feltételeket teremt a közösség neveléséhez. Véleményük szerint a közös munka a személyiség fejlődését számos irányban pozitívan befolyásolja. Egyetértettek abban, hogy a közös feladatok fejlesztik a gyerekek egymás iránti felelősségérzetét, és a közös problémamegoldás ráneveli a tanulókat egymás elgondolásainak figyelembevételére és tiszteletben tartására. Úgy gondolják, hogy a vita élénkítően hat a közösség és az egyén tevékenységére, és aktív tanulásra ösztönöz.

\section{A státuszproblémák kezelése}

A hallgatók 80\%-a válaszaiban első helyen említette meg, hogy a csoportmunka során alkalmazott szerepek elősegítik a csoporttagok közötti együttműködést, a mások iránti tisztelet kialakulását, a képességek sokoldalú fejlesztését, a státuszprobléma kezelését. 77\% úgy gondolta, hogy a csoporton belül kialakult hierarchia, rangsor az eltérő, sokféle képesség mozgósítására alkalmas feladatokon keresztül megváltoztatható (9. ábra).

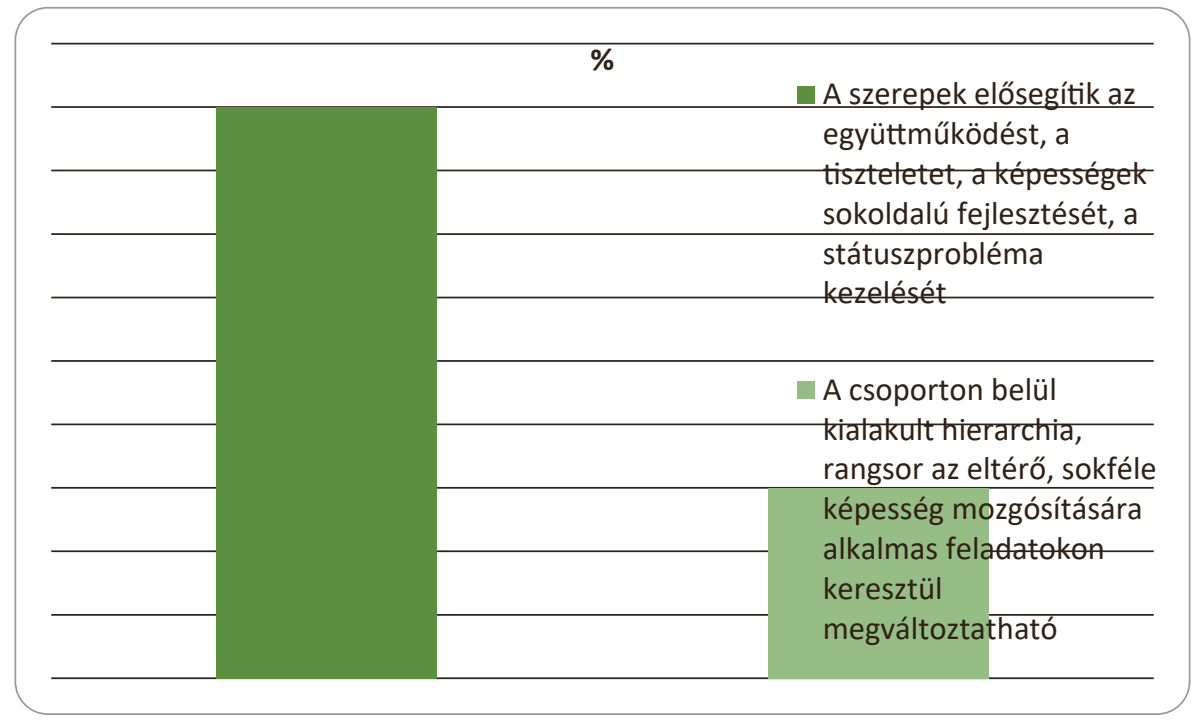

9. ábra. A hallgatók véleménye a módszer státuszkezelö hatásáról 
A Komplex Instrukciós Program alkalmas a tanulók közötti státuszrangsor rendezésére, amelyet a hallgatók megtanultak, és válaszaik szerint fontosnak tartanak. A munka során alkalmazott tanulói szerepek státusznövelő hatása, feladata szintén fontos helyet foglalt el a válaszok között.

\section{Összegzés}

A hallgatókat a hatékony módszerek alkalmazására úgy lehet felkészíteni, hogy új, kipróbált és bizonyított módszerekkel dolgoznak egyetemi éveik alatt mind a szemináriumokon, mind az iskolai gyakorlaton.

Munkánkban azt vizsgáltuk, hogy a státuszkezelő technika elsajátítása a módszerhez kapcsolódó, a hallgatók által elkészített óratervek minőségével mérhető-e. Mértük, hogy a hallgatók mennyire értették meg a Komplex Instrukciós Programnak a státuszkezelésre irányuló fontos tevékenységét, a nyitott végü feladatok és a differenciált egyéni feladatok szerkesztését. Ennek mérésére a módszer elveinek megfelelő feladatillusztráció összeállításában való jártasság vizsgálata bizonyult alkalmasnak. Az értékelésben a legfontosabb szempont a KIP elveinek való megfelelés, vagyis a központi téma körültekintő megfogalmazása, a feladatok nyitottvégűsége, komplexitása, differenciáltsága, a többféle képesség alkalmazhatóságának követelménye, a gyerekek egymásra utaltsága, de egyéni felelőssége és a csoport-, illetve az egyéni feladatok egymásra épülése volt.

Feltételezésünk, miszerint a Komplex Instrukciós Programnak a státuszkezelésre irányuló tevékenységének megértése értő interpretálásra kerül az óraterveken keresztül, bebizonyosodott. Úgy véljük, hogy a felsőoktatási intézmények feladata minél jobban felkészíteni a hallgatókat a módszer értő alkalmazására abból a célból, hogy úgy hagyják el a képző intézeteket, hogy alkalmasak legyenek a heterogén tanulói csoportok kezelésére, a tanóra sikeres megszervezésére.

Az összefüggések értelmezése további vizsgálatot igényel.

\section{Felhasznált irodalom}

Cohen, E. G. (1994): Restructuring the classroom: conditions for productive small groups. Review of Educational Research. https://doi.org/10.3102/00346543064001001

K. Nagy Emese (2007): Integrációs modell. A hejőkeresztúri IV. Béla Körzeti Általános Iskola tevékenysége. Fókusz 9, 1:36 -56.

K. Nagy E. (2015): KIP Könyv I-II. Miskolci Egyetemi Kiadó. 
Vigotszkij, L. Sz. (1978): Mind in society: The development of higher psychological process. Harvard University Press, Cambridge.

\section{Melléklet}

\section{Kérdőív a státuszkezelés ismereteinek felmérésére}

\section{Válaszoljon a kérdésekre!}

Miben látja a tanártréning célját és jelentőségét?

Adjon meg legalább három olyan ismérvet, amely az Ön számára a legnagyobb jelentőséggel bír a Komplex Instrukciós Program alkalmazásában!

Melyek a csoportalakítás szempontjai?

Milyen státuszkezelő eljárásokat ismer?

Az Ön órai munkáját mennyiben segítette a szakértői segítségadás?

2. Jelölje X-szel az Ön szerint igaz állitást!

Nincs minden diák birtokában minden fontos képességnek.

Nincs meg mindenkinek minden képessége.

Minden diák rendelkezik kiemelkedő intellektuális képességgel.

Néhány diák minden intellektuális képességgel rendelkezik. 